See discussions, stats, and author profiles for this publication at:

https://www.researchgate.net/publication/260831267

\title{
Information System Cost Estimating: A Management Perspective
}

Article in MIS Quarterly · June 1990

DOI: $10.2307 / 248774$

CITATIONS

49

6 authors, including:

\section{Rajesh Mirani}

University of Baltimore

28 PUBLICATIONS 551 CITATIONS

SEE PROFILE
READS

54

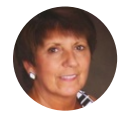

Carol E. Pollard

Appalachian State University 69 PUBLICATIONS 711 CITATIONS

SEE PROFILE

Some of the authors of this publication are also working on these related projects:

Project (To be Decided) View project

All content following this page was uploaded by Rajesh Mirani on 07 April 2015.

The user has requested enhancement of the downloaded file. 
Information System Cost Estimating: A Management Perspective

By: Albert L. Lederer

School of Business Administration

Oakland University

Rochester, Michigan 48309

Rajesh Mirani

Merrick School of Business

University of Baltimore

Baltimore, Maryland 21201

Boon Siong Neo

School of Accountancy and Comrnerce

Nanyang Technological Institute

Singapore

Republic of Singapore

Carol Pollard

School of Business \&

Administration

Duquesne University

Pittsburgh, Pennsylvania 15282

Jayesh Prasad

Katz Graduate School of Business

University of Pittsburgh

Pittsburgh, Pennsylvania 15260

K. Ramamurthy

School of Business Administration

University of Wisconsin-Milwaukee

Milwaukee, Wisconsin 53201

\section{Abstract}

Information systems cost estimating is an important management concern. An estimate helps to costjustify individual proposals, to schedule their development, to staff them, to control and monitor their pragress, and to evaluate estimators and implementers. Through a case study of a chemical manufacturer, the investigation reported in this article facilitates a better understanding of the management of the cost estimating process. Intervieurs with 17 information systems managers and staff members, and four user managens confirm that the practice of cost estimating oan be viewed in terms of both a Rational Model land a Political Model, can identify impediments to accurate estimating, and can provide suggestions and warnings for managers and luture researchers.

Keywords: Information systems, information management, planning, $\cos t$ estimation

ACM Categories: D.2.9, K.6.1, K.6.3

\section{Introduction}

In principle, the expected economic value of a proposed information system governs the decision to develop it. An organization conventionafly predicts the benefits of the system over its lifetime and estimates the costs of its initial developmeht and ongoing operations to identify that value (Emery, 1971; King and Schrems, 1978). Such financial techniques as net present value, return on investment, or internal rate of return are often used to combine and summarize tangible benefiss and costs (Guimaraes and Paxton, 1984). Ideally, a steering committee of senior managers evaluates these calculated figures, along with any avdilable intangible values, and plans a portfolio of applications (Drury, 1984; McKeen and Guimaraes, 1985).

The accurate prediction of benefits and costs is crucial because of this approval process. Overestimated benefits or underestimated costs dan result in the decision to develop projects that will ultimately fail to contribute to the organization and will waste scarce resources. Underestimated benefits or overestimated costs can resultin the decision to refrain from developing potehtially worthwhile projects. Thus, the failure to accurately assess all of the benefits and all of the costs can have a major, widespread impact on the organization.

The impact of inaccurate estimating has been so significant that it has reached the popular business press (BusinessWeek, 1988). This BusinessWeek article reports that a state of Oklahoma project was initially estimated at $\$ 500,000$, but was late completed at $\$ 4$ million. It also describes an A state Insurance system that was estimated at $\$ 100 \mathrm{mil}$ lion while under development; it was initially estimated at $\$ 8$ million. In fact, a recent Peat Ma rwick Mitchell \& Co. survey found that 35 percent of its 
largest clientis admitted metr costoteruns (Bus: rosshes, 1988; Suni catastroptes heve de stroved the credibility of 15 manecenent.

The most cignificani cost is the experditine for tint labor (i.e., systems anelysand programmertime) used to devolop in information system (Aller 1982). One study identifies the estimaton of latey raquirements as an imporiant is planning issuc among top is mangers (Laderor and Mendaten 1986). That research found hat these nonogers are concented abolit the sstimation of labor re quirement berause they mist tse these isguireTients to compte surall IS develoment costs. That sudy inctigated the researoh ropotadin the aticle whes objective was to berer understand th management of the labor cust estination procoss thiroligt the in-reptistudy of the techiniques ans problems of one organization.

\section{Background}

Frevious research recarding cosi totmation has srygty focussed on the stidy of algorithmic melioute. Thesemethods generalty hy thestin jor iestures.

First, they ropture some wollndeflad !our of knowledes of the proposed system. That is the

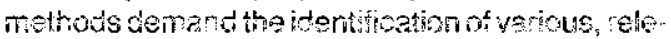
vart parameters. For example mary methods roGijethat the estimetoridentify the nutwer of hino of executzhls code in the proposod system (Boehm, 1984; Freiman and pack, 1979; Hard, ot al., 1977; Jensen, 1093 ; Nolson, 1966; Putnarí. 1978; Natson and Fo't\%, 1977; Wolvond, 197 if; Other tochiques fucus on the funcione of the pro posed system and might rondire such peremeres

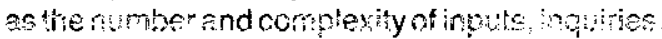
outputs, and masten filss (Alblecht, 1079; Dore: \$27, 1975; Halstsad, 1977; MCCabe, iz76). Oine? puticular method esks the estimators torate such

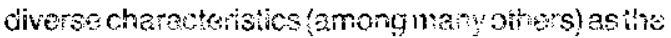
developers femilierty with the apdicetion, tho qualisy of the arialysis the projeciobjectives, and

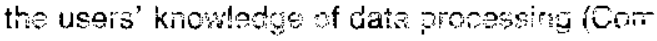
piter Asscoiates, $198 \%$;

Second, the menods genorally reguire sorre

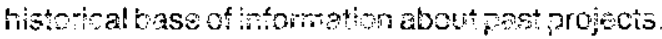
This iffomation inciuces durationectpredses Meti as some of the paraneters mertioned above

Third the mostods provide fomites that forecasi the cost of the propsetsystam. The romulas are

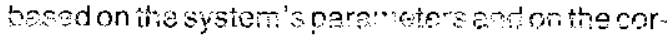
respring peraneteds and oosts of the sysers

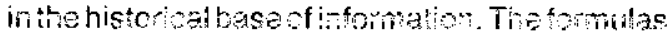
range from simple to complex in matrentitial sophistation. For oxemple, snteythe such sim plo summery statstics as means and gtandarde-

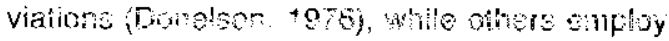

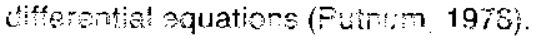

Objectivestudes of thesemethods hava hoen fow Qfen the developers o method doscribe their

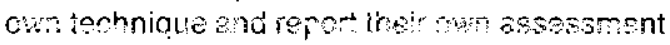
of its acrurecy (Domelsers, 1276; Jense:, 1935;

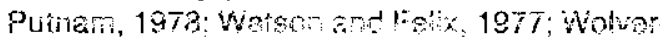
toni, 1974). Gtaer resaserch hae used the investigetor's full kncmledse of the scoes of completed propets to develop a tomule that wot: haveprodicted the projerts' haratios had heneo.

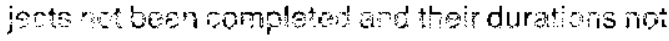
alrody known. (in contrast, one might expect the investipator to test a proposed formyla by pretiviing the duretion of resenty conceved proposs and ate their completion, contrasting the predited ard actial dutitions.)

For examole one study eveluated the sompey of four algothming noth by pradichotho dureilois of projects thathad already been comploteu (Komerer, 1387, However, it foind considarate

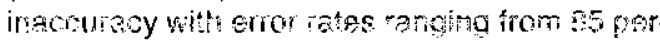
cont to 772 percent

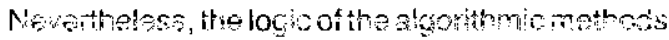

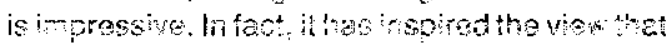
"tho wethods avalatetodgy are more then atequate to astabist an estimetion aporh Al! that

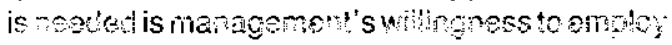
the piann agand control ptiblosphy used in othe:

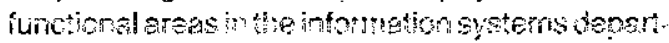
ment" (Bembasat and Veseoy, 1980, 0 . 1n attemptro to inderstand the management of the estimating process, this study reopgnizes that there is a question of the adequay of alonithmic metinds vers!ls the adequacy of the zpplication of plarmig and contol. it offers rev persper-

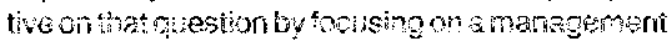
point of vis?

\section{Conduct of the Study}

This study oraploys a case methodolngy (Sor. besat, at al. 1987). A case methelolog : ap croprate in rosearch sint 2 s we mpinagement of costostmating, whom theory and resedot arein 
their early, formative stages (Roethlisberger, 1977). Moreover, the management of cost estimating is among those "sticky, practice-based problems where the experiences of the actors are important and the context of action critical" (Bonoma, 1983) and where a case methodology is warranted.

Accordingly, the authors gained the interest and cooperation of a chemicals manufacturer. The firm is the largest division of a Fortune 200 corporation. The division has approximately $\$ 1.6$ billion in annual revenue and 6,000 employees, of which over 250 are in the Information Systems Department (ISD). The ISD's annual budget is about \$22 million. User departments have a backlog of requests for limited ISD service and must make judicious decisions about proposed systems because their departmental budgets are charged for them. In light of its budget, its size, its well-defined standards and documentation, the experience and education levels of its management and staff, and its extensive computer-based applications, an independent observer would probably consider the ISD to be technically sophisticated and wellmanaged. This is important to remember because the ensuing discussion might make it appear otherwise.

The authors interviewed 17 ISD managers and professionals. During a structured interview, subjects were asked to: (1) identify their job titles, as shown in Table 1; (2) describe their job responsibilities, especially with regard to their roles in the cost estimating process, as shown in Table 1; (3) explain how systems' costs are estimated; (4) identify any potential causes of estimating problems; and (5) identify potential means of improving the estimation process. The authors also interviewed four representatives from the functional areas of the organization with essentially the same questions; these representatives had all participated extensively on ISD development projects. The interviewers supplemented the five main questions with requests for clarification and related information. Each interview lasted about one and a half hours.

Three authors participated in each interview for purposes of control. One particular author was present for all of the sessions, while the remaining authors rotated as the other two interviewers. Immediately after each session, notes were transcribed independently by each interviewer, then compared and cross-checked to develop final versions. Later, the authors independently encoded and summarized all of the subjects' answers to the questions.

In addition, the authors obtained and revewed management reports and data about past projects. A key ISD manager helped them obtain this information, choose interviewees, and verify clurrent findings.

The most comprehensive report showed primarily small projects from January 1 through May 17 , 1987. It covered 1,622 hours of labor over the 19-week period. Of all the projects on the report, 71.5 percent were completed beyond \pm 16 percent of the estimate that appeared on the report. Likewise, of all the projects on the report, 60 percent were completed beyond the wider range of \pm 20 percent. The greatest overruns included 60 percent, 64 percent, 119 percent, 247 percent, 520 percent, and 533 percent. However, most of those were small projects and hence, overruns or underruns might not be considered as deleterious as on larger projects. Nevertheless, they do suggest a potential problem in the area of cost estimating. In Figure 1, those data points olutside the diagonal lines represent the 71.5 percent of the organization's small projects completed beyond \pm 10 percent of their estimate.

At the conclusion of the study, the authors gave an oral presentation and a written report to d team of ISD managers. The subsequent disculssion confirmed that the authors had clearly understood the cost estimating process bf the organization.

\section{Two Perspectives}

The interviews revealed that ISD management had a documented method for managing the estimation process. Much of it was outlined in ISD'SStandards and Guidelines Manual. However, simultaneously, activities not described in the manual also took place. Such parallel, coexisting activities are suggested by Robey and Markus (1984).

Robey and Markus allude to the existence of a rational system development process in which ISD and user participants follow a prescribed set of phases to create an information system. They state that a rational process has an identifiable and agreed upon set of goals with a prescribed theans to achieve them.

Illustrating the rational process within the area of cost estimating is Jones' (1986) technique, talled 


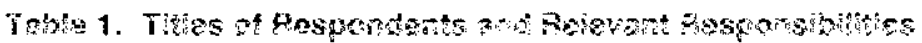

$$
\$ 50 \text { minthow }
$$

$1807+00+00$

Marager of Systera Dewelghen:

Marage, Financia! I-6maton Systenis

Manser, Marketng 'nomation Sysiems

Manager, Manurotibing and

Enginoerigg infomation Systems

Maneger of Systems Sortce cerre-

Semior Syetems Spocialist

Systeme Spenis!st

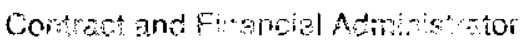

Manager of Syosns and Promoming Support

Manager of panning and Administration

Manage of Sytome ?lanniñ

Programentanalyet

Progronor

Contreot Programme:

\section{Controller}

Manauer of Cost and Lease Arcouriting

Manager of Purchasing

Marager of Engreerng Systoms

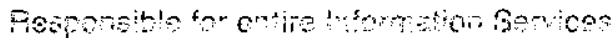
Paparenent

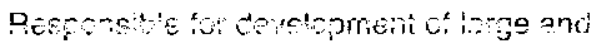
sonie enall aysters

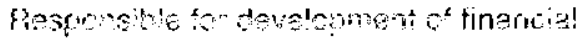
syotems

Pesponsto to dwotopment of mokethe syotems

Piesponsible tor dentepromes

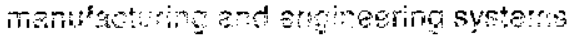

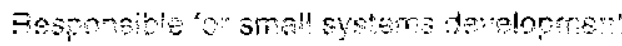
and meintenonoe projests

Seres as propt memage tor lase projects

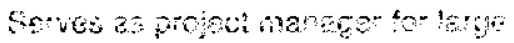
projorts

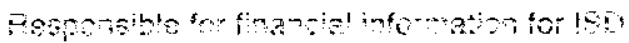
cimector

Fiundes techincel asciance to syeters spocialise progranmers atc

Posnonstbe to lone-range nermetion: systens plamning

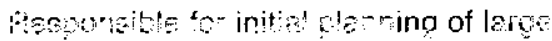
projers

Pespunsto for systems dovelopme-t and inaintenmes

Pesporsible for sustoms dovetoment and montsminge

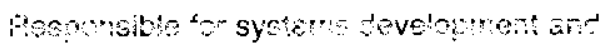
riminterane

\section{Users:}

Whid traront ofice and main user

Ligison for susteme desolopmon or aconimg aplications

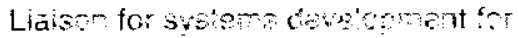
pursensing applichtions

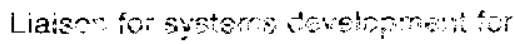
ongresring anpliatios 


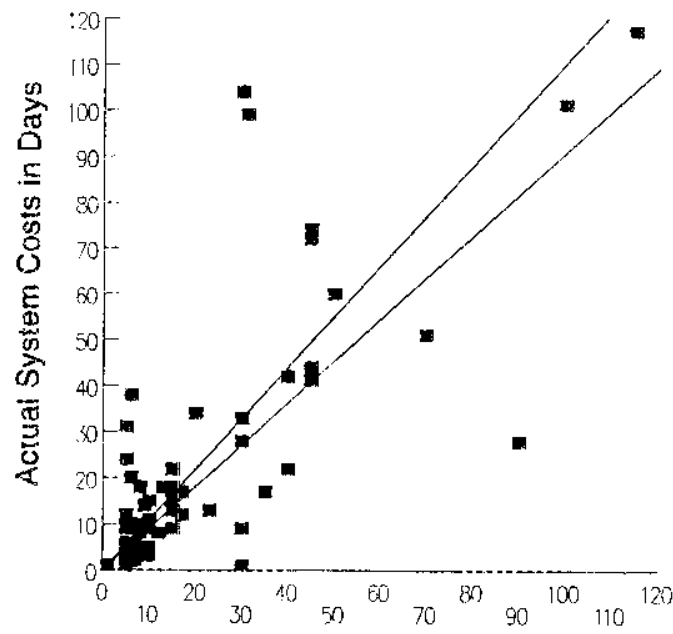

Estimated System Costs in Days

Figure 1. Estimates and Actuals

SPQR (software productivity, quality, and reliability). Based primarily on computations using 20 historical factors, SPQR predicts various types of systems development cost estimates and schedules, the rational process's identified and agreed upon goal. Examples of SPQR's major factors are programming languages used, program size, anc experience of programmers and design personnel. The use of these factors represents the rational process's prescribed means of achieving the goal.

However, Robey and Markus as well as other earlier reseatchers (Keen, 1981; Pfeffer, 1981; Wildavsky, 1979) recognize the inadequacy of a rational process as a means of understanding behavior. For example, Wildavsky (1979) analyzed the federal government's budgetary process and found the rational paradigm to be inefficient, ineffective, and inappropriate because most outcomes emerged not so much through the extensive planning that was performed, but rather through considerable bargaining and mutual adjustment.

The inadequacy of the rational model is echoed by Pfeffer (1978) who observed that it does not recognize the origin of the personal objectives that lead to conflicts of interest. Moreover, he recognizes that the rational approach does not account for the fact that the outcome of such conflicts can be interpreted in terms of who benefits and who loses.

Hence, Robey and Markus also suggest the existence of a political systems development process in which participants' personal motives inspire their actions. They state that the par- ticipants in a political process have differing objectives and may use the situation to achiel/se their objectives to the disadvantage of each other. Such motive-driven behavior has been helpful in behavioral analysis in both the IS and other contexts (Allison, 1971; Borun, 1980; Grover et a!., 1988; Keen, 1981; Lund, 1980).

The political approach recognizes that conflicts of interest are common and expected. It further recognizes the necessity to understand the participants, their stands on the issues, the determinants of their relative power, and their drocess of arriving at a final decision. Activities result from bargaining and compromise, and the rosulting decisions seldom reflect the preferences of asingle group (Alyison, 1971). Ultimately, the relative power of the participants provides both the sufficient and necessary means of reaching the decisioh (Pfeffer, 1978; Thompson and Tuden, 1959). In fact, with regard specifically to cost estimating; Jones proposes that "perhaps $10 \%$ to $15 \%$ of the really catastrophic project failures are at least partly caused by personal human dislikes and political or territorial disputes" (lones, 1986, ph 235), although he does not elucidate such condicts or formally include them in SPQR.

The next two sections describe the estimation process of the chemicals manufacturer. The first section describes a Rational Model in which the main identifiable and agreed upon goal is to provide an accurate estimate, and the prescribed means is a method of arriving at it. The second fection describes a Political Model in which the participants have different objectives and use the cost estimating process to realize them. Eactymodel reveals some of the management problems in estimating information systems development labor requirements.

\section{Evidence of the rational model}

In the Rational Model, five groups of employees from the chemical manufacturing company participate in systems development activities that are relevant to cost estimating:

1. ISD estimators: planners who work within the ISD to prepare initial project proposals; which include projected systems costs.

2. ISD implementers: systems analysts ahd programmers who develop the proposed system. They might also provide revised estimates, but frequently are not the same individuals who initially estimate costs. 
3. 50 management. sxectivos roenntstefor the !SD

4. User contacts laisons from the anolication area of the businesstotho1s0. They mightinot be actual systom users.

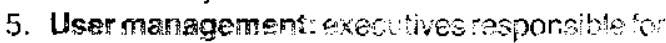
ine application area within the busiress organization

Under the Pationat Model, shese managers and their staff cariy ont the following planing and development phases of a typical systoms development life cycle approach (1)

\section{Phase +..The Initial Mrestigation}

User management or the tiser cont dut gererates an idea in this ohase. Tht porson or corp informally requests a provisional ostimate bu aknig any available ISD repressntative (1SO manager, estimator, of implementei) for this number. The ISD reoresemative gines a very rongh astingtor the sole purpose of enabling the reguestar to de cide whether to proced with these A Acording to a senior systems sperials in the Monufacturing and Enginestirg hnfometion Systeme gious the very rough Phase 1 astimete is ofter yory inaccurate becaise of the lark of kncwilartut about the scope of the project by al parties. The manager of Financia! friformetion Systems (and four other interviewees) further pcinted bit that the! 35 pe resentative assumes the estimate wil be forgotten when betrer estimates (i.e., based on iiore knowladge) are doveloped later an.

\section{Fhase 2-Proliminary System Stacy}

According to the marager of Qurchasing auser), fthe user contact bolicus that the system's ben. fits can exceed hhe Phase 1 cost estimate, a pe-

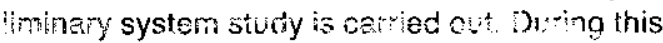
phase, the !SD estimator examines the proposed application in order to produce an initig!, sorious estimate.

The estimator roughs ont the syetem design to oroduce this astimate, a process describnd by the manager of Systems plannine. The estimatue frst identities modules of programs whth theirfunctions then determines filles, and next 3 ssasses the comiplexity level of each rnodule. Then the estimetor looks up ine number of days of anatys and proGramming for eact module in an existinc matrix of complexity lovels and durations. Finaly, the estimator sums the unber of bys and ariusts them based on experience and intlution. This a!
Gorithmic technique s rameafler rofence to as

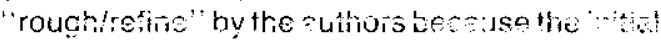

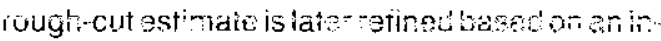
croasod understanding of inc aptoation ard the user "egutemente.

The maireger of Pirchasing (a asor) statec an the

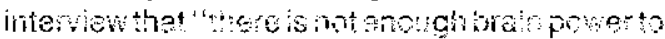
catch" all regirgmentsand that hombe Ish ran-

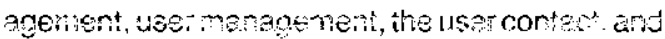

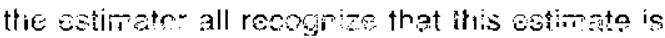

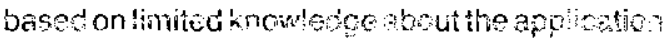

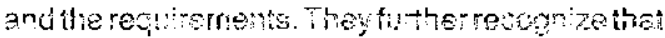

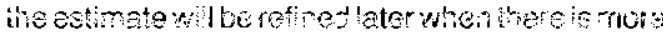
informatinin about the splication and reuture menus Nevorholess, it? Thase 2 ostirate must bo oftially aperved besed on the 3tandards and Guidelines Mama! lsi menagent usermait agenent, ins asor contast, and the estinator al! sign off on thit prase 2 sotimate to demonglate thoir aporova!.

\section{Phase 3-Surtem Fimpingh}

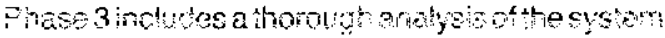
with sxtestye iserpartchatinn, and then, basod

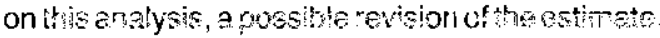
In the intorvew, tie nangyer sysens and Fu gremening Stpport stwhined the revision to the

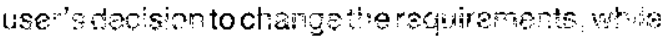
bot the rontroller and the nansger of Puratas ing (both usens) aitributed it to a lack of understert ing of the project. The nonager of Systems Planng stated that at hepromgothe phase

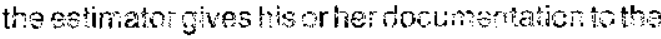
implementer at withdraws form the proper. Tino

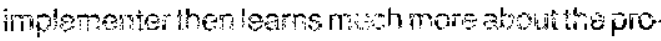
posed syetem durirg tis analysis

The ISO implementer applies the roughirefing techrigue to crode the piase 3 atimate if ithe ISD inplenerser's estineto sxrepts the Pnase 2 estimate, presumehy because of more know!. edge sbout the application and the requirernonts, then!SD managemert, tser managentent, and the

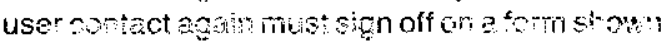

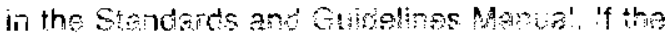

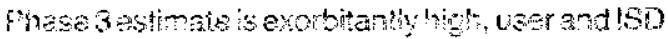

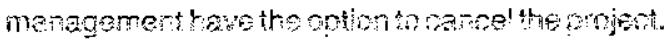

\section{Phase 4-.Systrm Design}

Phase 4 revesents tho rrepartion of debiled

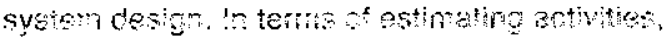
the mplementer uses rough rotha croo rean, but with considerably mors intormenas. As in 
Phase 3, if the Phase 4 estimate changes, signoff takes place. For example, in the interview, the controller described a stock transfer system that had originally been estimated at 100 man-days but was re-estimated at 200 man-days during the Phase 4 estimate. He threatened to cancel the project but signed off on this estimate instead because ISD told him that cancellation was impossible. Project cancellation does, however, often remain an option.

\section{Phase 5--Program Specifications}

The estimate probably remains unchanged while the ISD implementer writes the specifications for programming. If it changes, sign-off would again be required.

\section{Phases 6-10}

The next five phases are: Phase 6-_.Programming: Phase 7--Implementation Planning; Phase 8Testing; Phase 9-User Training; Phase 10-Implementation. During these phases, formal estimates are not prepared. However, should an overrun appear imminent, the ISD implementer informs user management and user contacts of the new completion target clate.

\section{Evidence of the political model}

Under the Political Model, the same grcups of employees participate in the systems development process. The Political Model, however, recognizes their motives, objectives, conflicts of interest, and relative power. The groups seek to utilize their power to determine the outcome of the decision process of agreeing on a cost estimate and thus authorizing further system development. Their overriding and governing objective is to make contributions to the organization in order to increase their visibility, demonstrate their competence and enhance their reputations. By showing that they are performing well, they can increase their responsibilities, their staffs (if they have any), and ultimately their financial compensation (a political stategy akin to the "Reputation Game," as proposed by Bardach (1977) and eluciclated by Grover, et al. (1988), in which parties attempt to persuade others that they are doing more or better than they actually are and thus increase their power).

Hence, they seek that the outcomes of the decision process facilitate this objetive. The specific means of influencing the decision and making their contributions visible may differ depending of their power and their responsibilities. To illustrate this Political Model, in coexistence with the Rational Model, brief examples (of which others might be identified) are given for each group of empldyees: (The subsequent extended discussion attributes assertions to specific interviewees.)

1. User contacts have the power to understate their needs in order to influence cost estimates. The source of this power is the user contacts' intimate understanding of proposed applications. User contacts might seek the approval of an expensive, new system that would increase the recognition of their contribution to their department. To obtain the approval of the initial proposal, user contacts can understate their needs and thus encourage an estimate low enough to gain approval. (Conversely, wh different objectives user contacts can overstate their needs.)

2. User management has the power to sway user contacts to understate (or overstate) their heeds in order to influence cost estimates. The fource of this power is user management's influence over user contacts' salaries and promotions. If user management seeks to readily bbtain more new systems to permit their subordinates to promptly complete more business-related work, they can encourage their user contacts to understate their needs, obtain low estirhates, and gain their approval.

3. ISD management has the power to sway estimators to inflate (or reduce) estimates because of their direct influence over estimators' salaries and promotions. ISD management might seek to install a particulat new system on time and within budget in order to increase corporate profits because such $\mathrm{a}$ contribution to the organization improves their reputation. In that case, ISD management might encourage estimators to inflate an estimate to ensure its timely completioh.

4. ISD estimators have the power to use their estimates to convince user management and ISD management to authorize new systems. If authorized and installed, the estimators' contribution will be acknowledged. If proposedd systems are not priced to sell (i.e., they are overpriced), managers will not authorize hem, they will not be installed, the organization will not achieve their benefits, and little recodnition 


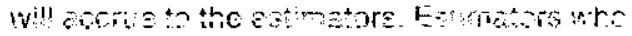

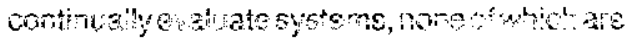

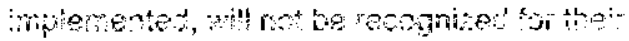

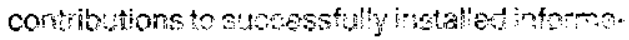
tion systeme The sotro of st stmetors' power is oit know suge of the detals of the astmating pocess.

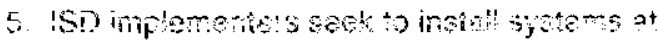

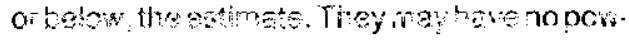
orintherezthorintylestmates. Howere by completing propots with" the estmates

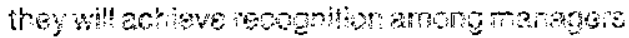

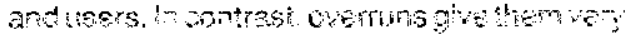
beit reputations

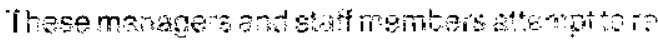

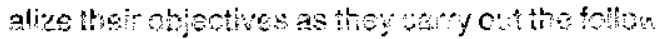

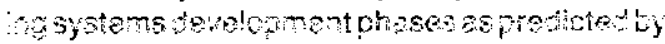

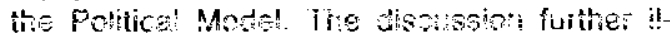

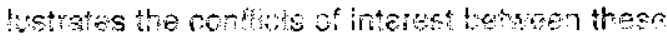

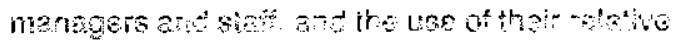
powarto resothe them.

\section{Phase - The nitial trustigation}

In inis phase, usc menagement on the ver oon.

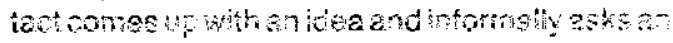
490 rapesentative to a prowsiont estinete

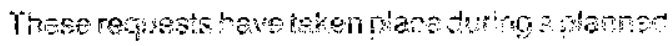

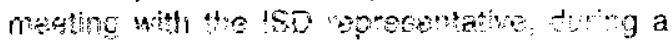

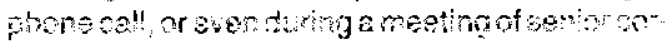
porat exacutives honocase a sentor avective

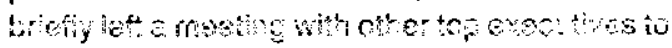

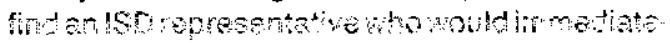

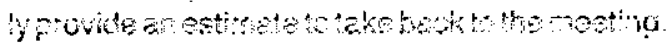
The 150 repsentaw whopridedteptimets hat ro provins knowlede of the promest syster.

Altough thene promelye patmetes tave tete:

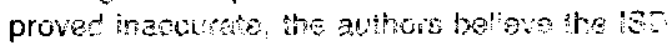

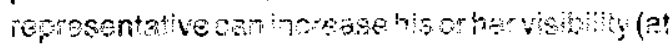

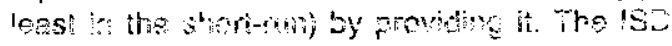

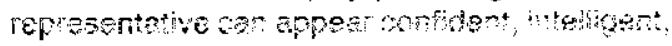

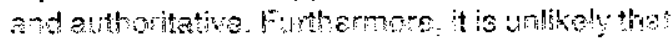

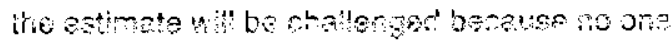
plseknowe the sroped the propect keopding to the marager of Fintasirg asery ant heopuse the application might rewhe developed acond hotheprophusefinethite Panderdsand Gudelines Marda! Lkentse the!So represen

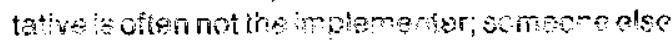

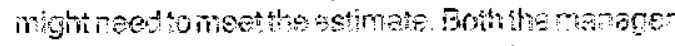
of the Systeme Sorke cener and the -ensos:

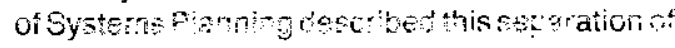

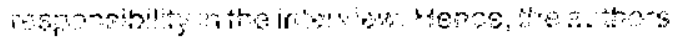

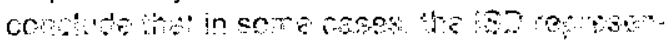

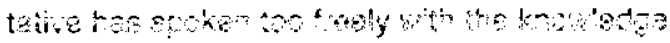

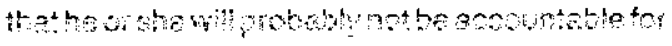
this extrato

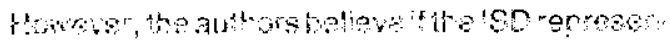

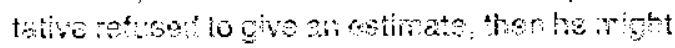

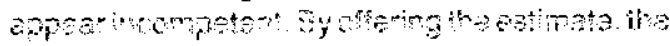
indives a! minhe segn very compent and very cainats

Uniche the prtonal Modet, whis assillet thet

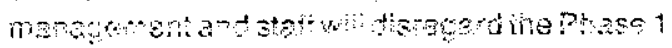

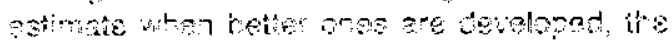

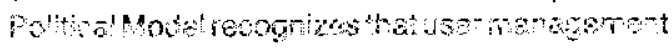

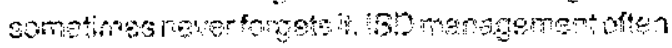

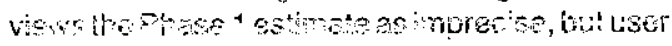

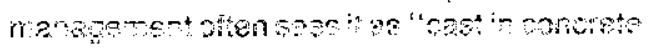

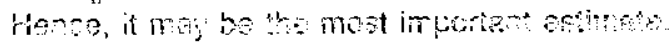

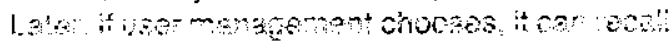

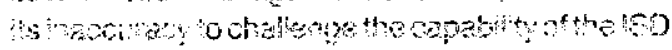

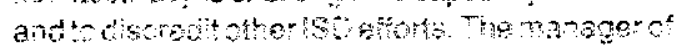

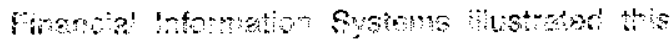

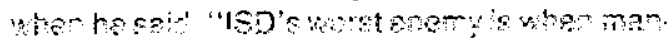

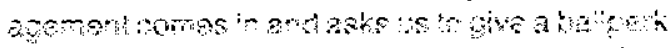

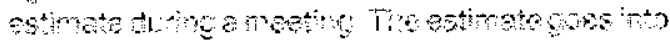

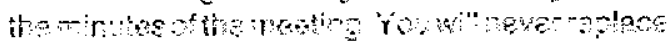

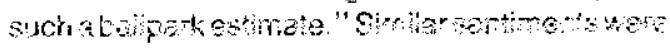

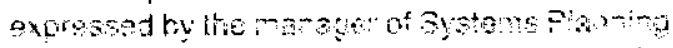

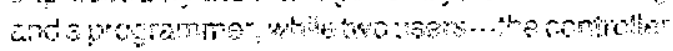

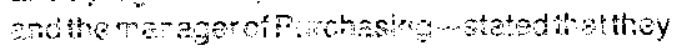

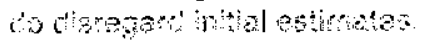

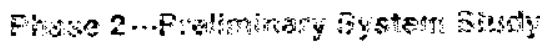

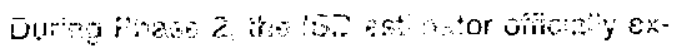

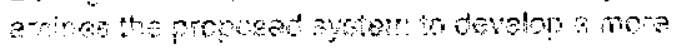

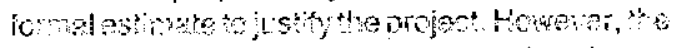

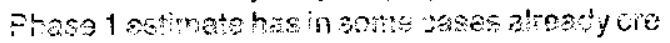

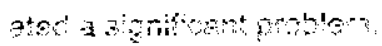

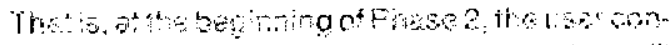

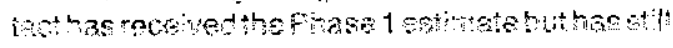

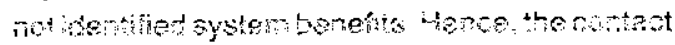

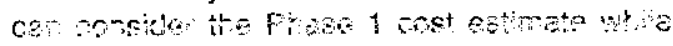

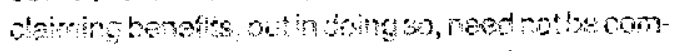

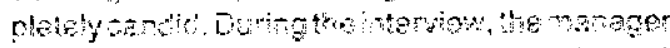

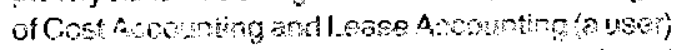

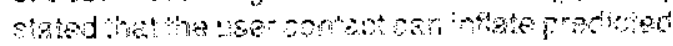

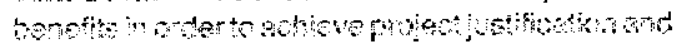

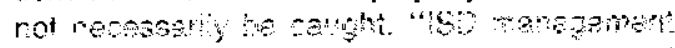

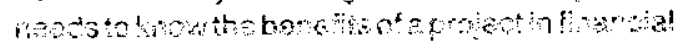

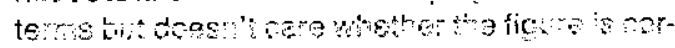

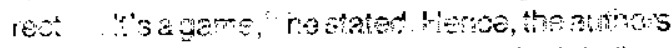

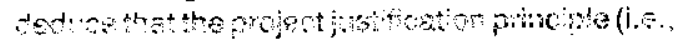


benefits must exceed costs) is compromisad by the benefits projection. The cost-benefits analysis presented in Phase 2 is sometimes fictional, and that estimating process might actually undermine project justification.

Moreover, if the user contact believes that the cost estimate will be too high (meaning it is impossible to reasonably fabricate offsetting benefits) yet wants the project authorized, then he or she sometimes reduces the project scope to increase its chance of acceptance. The ISD estimator lowers the estimate for the reduced project. However, the user contact may have privately planned to increase the scope in a later phase. The user contact finally does increase the scope and claims that the ISD estimator misunderstood the original requirements. For example, one interviewee, the manager of Marketing Information Systems, stated, "Users back off of their initial reques: to cut the estimate to get approval and then tack their earlier needs back on later to get what they had originally wanted."

The user contact has little difficulty carrying out this temporary scope reduction. The authors noted that the lack of an independent control or audit permits it Also, because some benefits are intangible and theirvalues are difficult to predict, the user contact can merely decrease their worth to pressure the ISD estimator to lower the cost estimate. A programmer/analyst and a contract progranmer who were interviewed both described such pres. sure to cut their estimate, while the manager of Marketing Information Systems stated, "ISO management might cut an estimate to meet a budgetary constraint. This cut is done after a review with upper-level ISD management who deem an estimate too high for whatever reason no matter how good the estimate was. . . Perhaps an agreement had been made at the Director level, an informal high-level agreement over lunch." Hence, the ISD estimator acquieces if he very much wants to achieve his objective of gaining project authorization.

This lowering of the cost estimate by the ISD estimator is not difficult. The authors observed that two flaws in the method permit the ISD estimators to create estimates that fit their objectives.

First, the method lacks firm objective criteria for categorizing modules by level of complexity. Eleven of the 17 ISD interviewees discussed this lack of objectivity. There are no written, or otherwise consistent and objective guidelines for this determination. That is, the estimator intuitively identifies the complexity level of each module. The ISD estimator is the systerns specialist most knowledgeable about the application and can lower the cost estimate by reducing the stated complexity level of the modules without being detected.

Second, the method assumes that all or most application functions are known. However, by nec essity, the Phase 2 estimate is prepared too quickly and therefore without a deep enough understanding of the application and its requirements. The ISD estimator can rely on a limited understanding of the application functions to supply a lower estimate.

After the ISD estimator has worked with the user contact to prepare the Phase 2 estimate, it must be officially approved according to the Stantards and Guidelines Manual. Two negotiations take place to gain approval. First, ISD managemeht and the ISD estimator negotiate the estimate. fen of the 17 ISD interviewees discussed this negosiation process. Generally, ISD management wants to reduce the estimate. The manager of Systems Development referred to cost estimates when he said, "They're too high and I want the job done quicker. . . whatever they come up with." The ISD estimator (particularly if he or she expects to be the implementer) wants to maintain it. A cohtract programmer admitted that he built 10 percent to 15 percent slack into his estimates to be prepared for unexpected changes, and added, "It is better to come in under than over. There is a little pplitics involved." Nevertheless, ISD management sometimes persuades the ISD estimator to reduce the estimate.

The rationale behind this possible reduction is an ISD management belief that by reducing an estimated cost, an actual cost can also be reduced. The manager of Systems Development illustrated this with his previous quote. Presumably, acoording to him, systems analysts and programmers wili work harder if pressured to meet a lower estimate. Furthermore, ISD management sometimes suspects that the ISD estimator (especially if he or she will later be the implementer) may have adreadly excessively padded the estimate in order to prevent an overrun. A senior systems specialist nterviewee stated that his "little extra padding" was not excessive but that ISD management triled to remove it with an ensuing argument. Six $1 S D$ interviewees acknowledged the reduction of padding. 
Tinus, the authors concluded that if ISO manage ment dees beliove ari estimate is ton high (whore too high means thiat user marugement wh not authorize the propot? then it somethes fower: the estimate to anhance thechance of aroptencs. ISD management can do this because no one is likely to successtullyprotest lihe estimete will bo an established foet when the SO inglenenter first sees it Furthermore, the iSo inplementer will rot protest if ISD manasenent hes perpesed that it failure to meet the estmate will wul affect the next performance review. Cne programmeranalyst and a senior systems specialist stated that during performance svaluations, they worenot accourta. ble for meeting estimates, while the managers of Manufacturngand Enginegring Information Systems, of Marketing toformation Systems, and of Finencia! Information Systems stated that the; held their subordinates accountable.

The second negoliation is botween ISO manago ment and use managerrent. User managemen: usually wants a lower estimate (implying a lowe: fina! cost, while !so manageneri usually wante to maintain the level of the estmate to prevent a overum. The manager of Enginearing Systems (a user) illustrated the former point when he suggested that his department diu not wamt o "over spend," while the manage of Systems and Pro gramming Supporl illustrated the latter point by stating that ISO was concerned atort ty norceived accuracy in estimating. This regctialon ss limited because user management cannet nogotiate on the basis of any understending of the selimating process. The manager of Cost and Laser Accolnt ing, the manags of Purchasing. and the menage of Engineering Systems (at sears, confirmed that they did not underetznd the mears whereby 180 arrived at itsestimalos Nevetheless, the nsgotiction sometimes forces both parties nto infoxible pesitions. It ras force user rrenagement to theaten project cancollation if the estimate is now lowered, as illustrated by the threat of the cancells. tion of ar imports order anty project Convereely, it can prevent iso management from lowering its estimate wittrout ievealing that the estmate wat based on subjectivity and a lack of understanding: of the application and raquirements. For instance, ISD could not sufficiently lower the mporte orde? entry project estiruate because it could not explam the rationale behind the original estimete.

Sign off completes the Phase 2 estrrate approvat process. Its purpose might apgear to ensure an acouratestimate. However, the suraturanthe
Phase? estimetenather onoure the acoi roy of the estimete rer approveits correctness. 'neted, user hanagement signe to indlcats a willingress to pay the estimete. Acoording to the mareger of Engneoting Systeme (a ver), "Sign off iealy does not mean much." ISD marrgement signs to ind cate thet the s su wil! develop the ovswm. The manape of Systems Dovelopment stated that there were enough ohe signetues on the docu

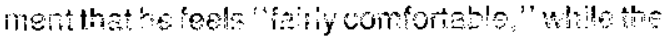
manager of Marketing hormation Sysems stated ind he signaiure refects chiv an acoptance of ine estmole because she "rarely gets dirocthy volved in estimeting. "Conthe estmator's signa tureatmat the estmate Ther signature indicates thet soneone (prohaty someone ofsel cancomplote the projent withir the astimate.

\section{Fhase ₹-.-Syctem Fianong}

Fhase 3 incledes a thomgh arelysis of the system with extencikeuser perthperion, and besent on it, a possible cevision of the estrnete. Aroording to

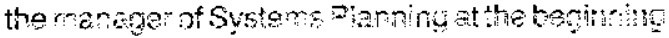
of this phase the estimator rivesthe dacumente tion to the mplementer and whirews from the project. The miptementer leath more about the proposed systam ding his analys's

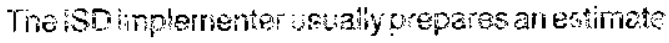

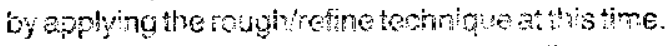
Whon dong se the implemonter ofien discovers

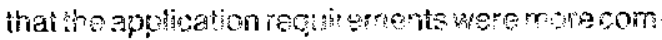

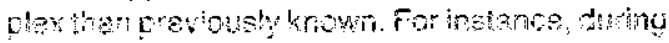
the hentem, the controber (a ued) desc ibes a siock transfer projert in which such a disowery took plare. Hence, the implementer sometimes wants to interse the nimber and conplex of programs to raise the astimate and lewe the chances of overun. A Eenior systems specialisi ctated thath had to wh as mon patding Phase 3 as possible tecause marexplaration matd bo required if he tried to per in thase 4

Usually, huweve, the 60 mplemente declines to cherge the estmate Thom inence of the Prase

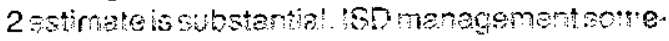
times forces the lntertenter keep it A procrat mertanalys? stated in he interven thet she has no lde how her menager hat arrived at these 1

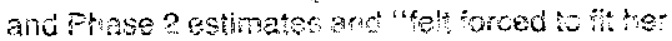

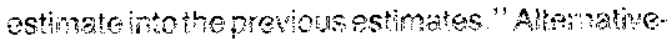
ly, the 150 implementer sometmes chousete preventany emarasenenthe tho that arhenge

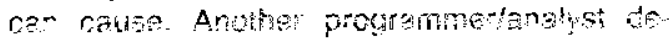


scribed a system originally estimated at 220 days, but later re-estimated at 340 days; however, the original number was used to set up a target date and prevent ary embarrassment in the eyes of the users.

Moreover, the implementer sometimes does not feel confident contradicting the Phase 2 estimate. This is because the implementer assumes that the ISD estimator better understood the system during Phase 2 than he or she (the ISD implementer) does in Phase 3. One programmer/analyst expressed lack of confidence doing so because Phase 1 and 2 estimates were usually done by more experienced senior systems specialists or planners. Thus, the manager of Marketing Information Systems stated that of the seven or eight major systems she had seen estimated, only the estimate of ore had been officially changed.

Nevertheless, the user contact's requirements sometime change. The user contact learns more about the potential of a new system. The manager of Systems and Programming Support described how both the users and ISD recognized the growth of the users' requirements during the development of a material requirements planning system. The user's needs (or understanding of those needs) grow, and hence the system requirements grow. Both the user contact and the ISD implementer usually recognize these new needs.

Thus, the ISD implementer wants to increase the estimate to reflect the new requirements ard then have the user contact sign off on the new Phase 3 estimate. However, the user contact sometimes wants to maintain the Phase 2 estimate because an increase could imply his or her incompetence during Phase 2. The manager of Cost and Lease Accounting (a user) pointed out that because users for whom he served as liaison depended on timely project completion, changes to target dates were an embarrassment for him.

To prevent the ISD implementer from raising the competency issue, the user contact sometimes suggests that the ISD estimator or ISD implementer failed to understand the organization's needs and also failed to explain all of the system's possibilities earlier in the development process. Many interviewees aclmitted that the failure to understand user requirements was a major impediment to accurate estimates. For example, the controller (a user) stated, "ISD and Accounting initially thought that they understood a written document describing a project but later learned that they did not. They had different interpretations." Thus, to avoid criticisms, the ISD implementer simply chooses to keep the Phase 2 estimate, when in fact, it should be increased. A senior systems specialist commented that "lots of explainht is necessary if there is a change of greater than 20 percent."

\section{Phase 4--System Design}

Phase 4 represents the preparation of a detailed system design. In terms of estimating activities, the implementer uses rough/refine once agaln, but with a considerably better understanding of the proposed system.

Conflict between the ISD implementer and user contact at times occurs as in Phase 3 . The resulting Phase 4 estimate differs from the Phase 3 estimate.

\section{Phase 5-Program Specifications}

Generally, a new estimate is not prepared during this phase because of limited user contact.

\section{Phase 6-Programming}

ISD has the best handle on estimating during Phase 6, according to a senior systems specialist that was interviewed. Thus, some estimates have changed during this phase. When this happens, the ISD implementer must obtain a sign-off on a new estimate or must attempt to meet the previous estimate to avoid an overrun.

The ISD implementer uses three basic tacfics to meet the estimate (i.e., substantiate its accuracy) and avoid an overrun. The first tactic is to defer deliverables. That is, the ISD implementer identifies a portion of the system and promises to complete it on schedule, while delaying the completion of the remainder. In this way, the ISD implementer can argue that most of the system has beer completed within the estimate. The manager of Systems Planning illustrated this by saying, "It sometimes ends up that you do what you can for the amount of money approved. This budgetary limit sometimes translated into deferred items:"

The ISD implementer's second tactic is to work harder and faster. Since systems developnent is largely mental work, ISD implementers are able to work harder and faster when under pre $\$$ sure. "Crashing the project" sometimes brings it in within its estimate. For example, the manager of Systems and Programming Support stated, "If a 
system Cverruris, ISD woiks cvertime so that the user does not know about he overy ". A programmerlanalysi addad, "Mpeting a comptotiun date is the real issue. You have to wnt overtine to mogt the date if thete is insufficiant staft."

The !So implementer's thited terte is to refrain from recording hours workeci on the poject or to sesime them to oher kase. Tise absence of trerking of overtime hours makes this apecialy assy too. complish. Hence, "creative acounting" wemite the 180 irmplementer to appear to neet the est mote. As the manager of Systems and Togram Ting Supportponted üul, "ISD never tets the user about a mistake. They whitd rathor assign add. tirnal resources not charged to the use.".

\section{Fhase 7-mplementation Plannipy: Phase z-Tastimg:}

in twms of rocogning ovemens, these phases resemble phase 6 .

\section{Fugse 9-ubser înging}

Trere are no estimating activites in tis phese

\section{Phase 10-mplementation}

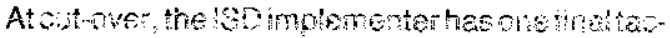
tic to create the anoearance of having not the estimate. He or sha can lotly clam that the projer wes completed with h the estimate eve ryat ap pears not to have bees the case. The 150 imple menter can doclare that the user contant dastion attered the reouirements during develonment and thet any afperentoverun wes shribitablo to the Honce, the is inplonsenter can assenthet the estmete was accuratend the orginalpropwes. or would have bepr, compiated wisto ha ost. mate. The marager of Systems and Progemining Support intutrated this belkef when he stated nat "the majo problem is the poroppton of iras. curacy" berause of significant changer in use: regurements rather that bocause of nocurate estimating per se.

\section{Another view of the two perspentives}

While the evidence for the lyationa! and poltical Models oame primatly fom the interigers reguest that subjects oxplain hom coss were est. moted, the answers to the request to identify aniy petentia! causes of estimating problems can be in terpreted similarly as on the answas ow the re quest to dentifyme potentia! nogns for imponng

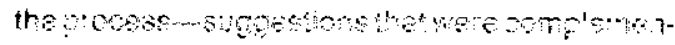

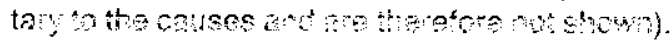
Table 2 shopethat 10 most tropumymentomed

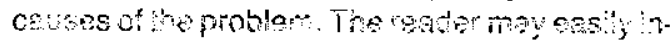
ivpet then an legitmate cavss of inowurate

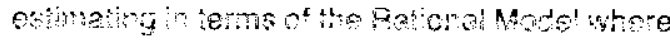
the process bas an spred troon and stated goal of poving an acourate osthate However, the

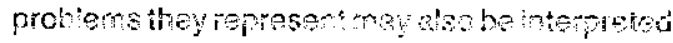
underthe Poltich Model as oportunities fur pir

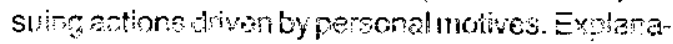
thes for each tem : I Trbe 2 convey this interpatation

\section{Summary and conclusions}

llsor andist mengemont densnd ruch of an

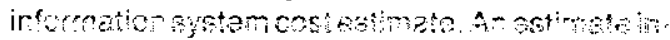
itisty helps th tifyech indwdul proposaland

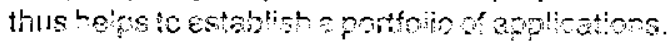
Morover, thestinate on abo seve ta sohoduts the devolopmen of the appliation, to steft to control and monitor ite prezrese, to evattate set. matrs and invenerber and oven to maket ?

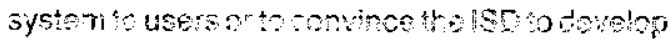

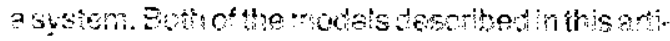

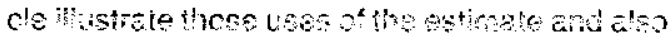

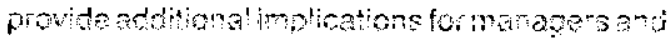
resentehes

\section{Implications for mangers}

The atudy's ricel important inflication to is moregers is the formal recompiton of the exis-

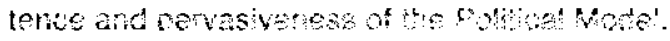
At the atine pesentaton of the findings to the

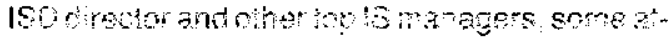

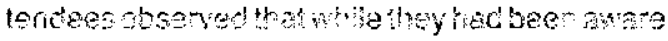
of ind of their crgandatise's polites they hed rover beforedtad there ritt hesomayexances of thin a single sctity. Trotomonsthed its petentiri perastanssend and possbe de-

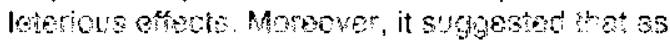

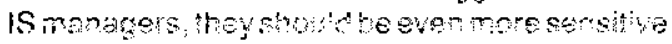
to it than they rad bew and the they stroud be

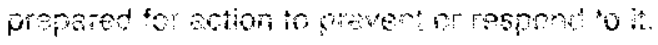

At that presenton, the authe proved the

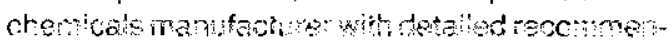

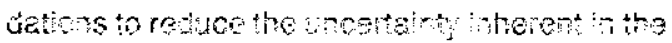
ockereting procoss and thereby improte its zrcumby There recmmondators wempined ty

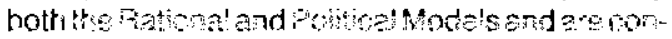

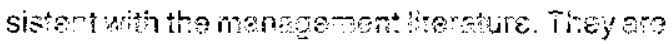


Table 2. Potential Causes of Estimating Problems

1. Inability to anticipate programmer characteristics (10)

2. Sloppy estimating with overlooked tasks (8)

3. Insufficient user/analyst communication and understanding (7)

4. Lack of methodology or guidelines (5)

5. Lack of coordination of ISD functions (5)

6. Management removal of padding (5)

7. Lack of setting and review of standards (4)

8. Lack of historical data (4)

9. Frequent user change requests (4)

10. Changes in ISD personnel (4)
The estimate considers the skill level of the eventual programmer. However, the identity of the programmdr is not known when the estimate is prepared. This uncertainty will enable the estimator to increase the estimate later or to explain an overrun by claiming that he or she expected more capable programmers. Thits he or she avoids culpability for the overrun.

The estimator can rely on his or her lack of understanding of the application (with the resulting overlooked tasks) to justify an increase in the estimate. The estimator may claim that the lack of understanding arose from insufficient explanations from the use.

As in \#2, both estimator and user can claim that the other's failure to communicate resulted in the need to increase the estimate.

The lack of objective guidelines for identifying the level of complexity of a program gives the estimator latitude in assigning the estimate with little challenge

Each of the ISD areas, such as Planning, Systems Development, Database Administration, and Operations, have their own needs and priorities. Delays in one area affect the schedules of many projects. Late in the development cycle, the estimator attributes the need for a new estimate or for an overrun to the failute of other areas to deliver their resources when needed.

The estimator seeks a high estimate to prevent an overrun while management seeks a lower estimate in order to provide less costly service.

The lack of agreed-upon durations for programs of each complexity gives the estimator flexibility in assigning the estimate.

Similar to \#7, the lack of well-kept records of previous projects gives the estimator flexibility in assigning the estimate.

The implementer can attribute the need to change the estimate to new user requirements.

The estimator can attribute the need to change the estimate to errors by personnel formerly associated with the project.

Note: Number in parentheses denotes number of interviewees who mentioned that cause. 


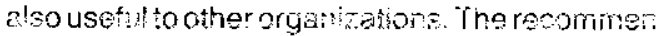
dations are:

1. Equastirg" A ccurse for inexperienced users to help them understand the importence of ex plaining their reeds lo ssimators and acours: for $1 S 0$ estimators to help them teare to bette: elicit user reeds. Both of those recommendetions reduce the uncertainty of the estimating process as imposed by undear requirements They are consistent with Galbratt's i 1977 ; observation that the increased perticioation of lower lovel crganizational members indecison making can holp reduse task unostainty.

2. Marketing: Fecutve bresings, whit paper, and newsletters encourage user commitment, help dispel the perception that all 150 projects wil! overrun their estimates, and encourage mutual adjustment and communications. These recommendations represent Thorn? son's (1967) asserion that as organizatona! units move frompoded interdependerce tose auential or resprocal interdependencs, coordination is best achieved by mutual adustment and communications.

3. Managing: Procedures for reducino conílicts such as the implementation of a new project manegement and control systen, the inclementation of an intermal 50 a a dining function the incrased involyoment sfimplementers in the estimation process, the protibition of the premature guoting of an estimate, thereward ing of project complotion within the astivatet serve as ai incentive to estimaters and in: plementers, and the requirement for a more detailed statement of bonefits before cost estimating. The new project managenent and control system and the rewards for timely proisct conpletion illustrate Ouchi's (1979) : that linking petormence (arcluate estimates) to incontiver is walvable when outputs (the ac curacy of estimetes) are easily monitored, biti atransformation process (the recreating of the sstimate) is difficult to monitor

4. Tracking and controlling: !mplementation of a detailed stardardized and periodical progress reponing systen, ito development of a new comprohusive cherlist of potentid! system development tasks, and 2 more thorough collention of historical data. These procedures inlustrate Cyet and March's(1363) suggestion that uncertainty ran be ovolded by imposing stender operting urocedures sad industry tiredition.

5. Aubling: A more carefin check of twered

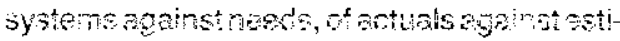
mates, of user olamod borefts of tha mooress of porect development, of the adherence to change request sigin fit, and of the accuiany of project controf systom soorts.

6. Esthmating: inpinarent of the existing rolghthetine methodelog on the acquisition of a cost-ostminting of whe pockase.

By attempting to reconde the we models these recomnendations could dead to estmates olose to their thote actual cosis. The merkehgonu

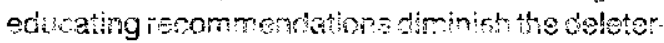

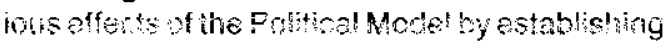
constructwe attitudes that ompharze cooceration and cando The mansegng tracking and contolling, and anditing recommendations redve the dewrinend aftents of the froligal Model by therk ing and ostraining comberorodudive notivedruen bohavior. Tho monaginy, trackina and cor. trolliny, dudting, and estimeting recommendetions anticipate and prevent many sincere oversingte resuthing from the Fatonal Model. Hence, the process would be r r proved by being left indther sntirely to the whins of the politics of the oroanization rom to the stroteming of the monagers, astimators, mplementers, andicers.

The SSD drast tesponded to thes recommendaticns at the gresentation by stating his intent to implemori a res projent runacoment arj cưn-

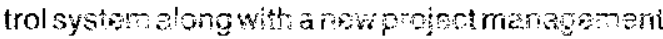
anu costestming tainirg orogram for 180 estimators and implemeners we also saithathe and his menagers wold consice cher reommendation Sewera! of the intervewes stated th at the study made the nnereaware fhe probloms of cost estimating Earh hed experienred some of the confliet desoibed in the suly, but none had proviously reogrizad their widospread impact on sach other.

However, meny of the recommendatiolis repre. sentod politically sensitve and time-coneuningectivitiss Several of them would limst the flexitilly of the maragers responsible tor the approva! Othors would demend wore the from slready busvuses thorsover the sponser of the study and

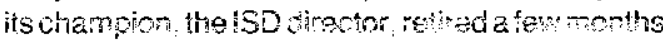

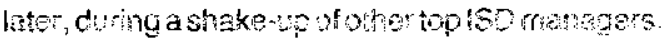
Hence, a your and a pait after the stijty, the 
chemicals manufacturer had followed merely one recommendation-the trial acquisition of a new estimating software package - but was still strongly considering a new project management and control system, as well as several other recommendations. The delay in management action was probably attributed in large part to the ISD management changes.

\section{Implications for researchers}

This research has provided an independent case study validation of Robey and Markus' (1984) proposed Rational and Political Models of IS development. The research extends their initial, sparse, and illustrative examples of the models into an indepth analysis of a specific, critical dimension of IS development. No research had previously attempted to validate and extend those models in such a fashion. Moreover, the study offers the following implications for future researchers to consider in their investigations of cost estimating.

The Rational Model illustrates that the creation of an estimate is not a single event, but is instead, a multiple, serial process of considerable effort to continuously create, refine, and perfect a number. This suggests that when researchers objectively study algorithmic estimating methods, they need to record the actual estimates from each development phase to compare to the actual, final project duration.

The Rational Model also illustrates the importance of an estimate early in the development process. User and ISD management need the estimate well before ISD estimators can thoroughly understand the requirements of the proposed information system. Hence, methods that can provide early estimates are particularly valuable and are thus an important target for research.

In contrast, the Political Model reveals an estimation process with perhaps greater resemblance to a game of tug-of-war than to a prescribed management process. It demonstrates that participants in the system development process may be driven more by personal objectives than by organizational goals. Their fear of overrun and project cancellation may carry considerable influence. While this case research has revealed the existence of some error in cost estimating explainable by the Political Model, future research should assess the impact of that error. It may be significant.
Moreover, the research implications of the Political Model contradicts those of the Rational Mqdel in an unexpected way. While the Rational Model sug gests the use of objective studies comparihg actual durations with the actual estimates from each phase, the Political Model disputes the accuracy of the actuals. Indeed, the "creative accounting" of project durations may invalidate such research. Researchers should investigate the extensikeness of "creative accounting" and should take dare to ensure that estimates and actuals used in their research are as accurate as possible.

Most important, the Political Model demonstrates that the participants can attempt to subvert the Rational Model in order to achieve their own bbjectives. The possibility of their success ralses a question mentioned earlier: Is cost estimating a management concern because of ineffective techniques or because of the poor planning and control of the estimating and development process?

Undoubtedly, the proponents of estimating techniques would argue in favor of the logic andd elegance of their methods and would assert that managers simply must control their subordinates. Conversely, managers might argue that the methods fail to provide an accurate estimate early enough in the development process. In addition, ISD managers might argue that the methods' in. put parameters are easily compromised because they rely too heavily on the expertise and subjectivity of the user contact, ISD estimator, and ISD implementer.

This article has not definitively answered the question of whether poor estimating techniques or poor planning and control are responsible for making cost estimating a management concern. Still, by focussing on a management point of view ahd by considering the Rational and Political Models, it has provided a new perspective on cost estim ating for further debate and investigation.

However, a single case study might not accurately represent cost estimating in all other firms. Therefore, with this case as the point of depatture, researchers should study the management of cost estimating with a larger sample for the testing of hypotheses. They should attempt to ascerta n the actual state of practice in cost estimating with such a sample. Finally, they should attempt to determine the extent to which the observations in this case study hold true and the extent to which they actually affect the process of informition management. 


\section{Peferances}

Abroht AJ. "Measurng Applioaton powolo ment Productivity," GUDE/SHARE Applice tion Developmen' Symosium Frocedigs. Monterey, CA, October 1979, pp 83.9 ?

Aller a. "An Unmanaged Computer Syetomear

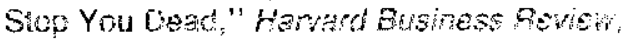
November. December 1982, .p. 77-37.

Allison, G.j. Essence of Dedision Lithe stown and Co., Boston, MA, 1971.

Bardach, E. The Implewentation Garm: What Happens Aftor a Bill Becomes a Law MY! Press, Carrontge, MA $19 \%$.

Benbases, ". and Vessey, $\therefore$ "Progremmer and Analyst The/Cost Estimation," MAS Puarer $y(4: 2)$, June 1980 , po $30-43$

Eenbasat I., Goldster, D.K and Meat, M "Ths Case Rosearch Strategy in Studias of infomen tion Systerrs," Mis Quarterly (11:3). Sez. tember 1387 , pp. $369-388$.

Boehn, B.W. "Sothare Hngineering Economins," IEEE Transactions on Sofware Engineer. ing. January 1884, po. 4 ?.

Eonoma, T.V. "A Case Strudy in Cese Gasearch. Marketing implementetion," Wokkng Pane: a-585-442, Harvad University Eadiats School of Business Administration, Boston, MA, Mav 1983.

Boun F. "A Pown-Shategy Atematue to Organization Developmer!" Oranization Sirdies (1:c), 1980, pp. 123*14s.

Businessweek. "It's Latse, Crostly, hoompetent.-.. But Try Fining a Computer Systen," "ssue 3078 , November?, 1988, pp. 154-165.

Computer Associates CA-ESTMACS An Apot cations Development Froject Estination Sye tem, Mt Labre! N! 1987.

Cyort, R.M. and March, J.G. A Sehaviol Theory of the cim. Frentice.4m, no. Englewoon Clifis: NJ, 1963

Donelson, W.S "Prolect Finning and Comol," Datamation, June $1970, \mathrm{pp} .73-50$.

Drury, DH. "An Exaluation of Data Precessing Steering Committes, MS Quarerly (B:A), December 1994, 00. 257-255.

Emery, J.C. CostBenefit Afalysis of homation Systems, The Society to Managoment toto mation Systerns, Chicago, iL. 1971 , pp. $18-48$

Freman, F.R. and Park, P.D. "PRIOE Softure Model-Version 3 An Overvew," Proceeding

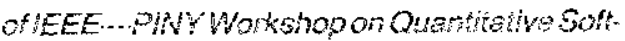
Ware Modsls, IEEE Cat. THO067.9, Kamesha NY, October 1979 no $32-41$

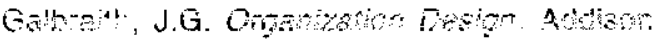
Wertu, Reating Ma 19?T.

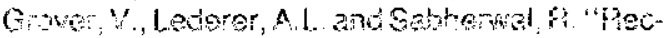

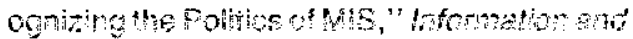

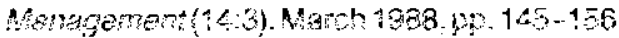

Gumaras T. andPaxton, WE "impatofinan

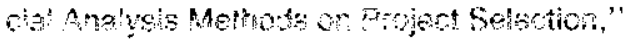
Jound of Systoms Managemen. Fobmary $198, p p \cdot 18 \cdot 2 \mathrm{c}$.

Halstea, M.H. Elemens of Sotware Science ElEever Morth Holland, Now Yok NY, 1977.

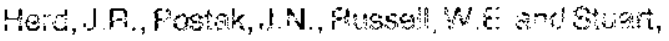
K.F? Solware Cost Estmation Sudy ...SAnty Pesuls, Final Teohnical Peont Pano-

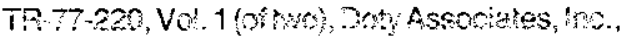
Hocking, MO, June 197

Jansen, P.W. "Anlmprowed Marrolovel Software Eovglounent fleswroe Eslmatom Made!"

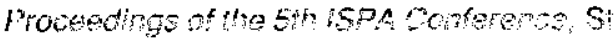
Lovis. MO, Apri! 198 , pr. 384.399

Jones, Crogramming Prodtctivity, MoGraw thit New York, NY, 1986

Kenerer, C. "Ar Empirical Validation of Sotowste Cost cstmation Mecels," Oommuriczions of

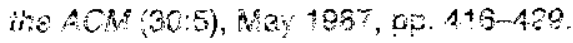

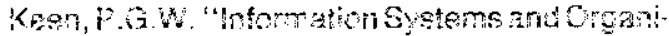
zatichat Onghas" Commmications of the ACO (2s:1), Januay topt, op 24-32.

Kng, IL and Sehems, Fe.L. "Cost-Bhnett Andysis in Intornation Systens Developmer: and Operation," Computing Sirveys (10:1), March 1978, po 10 34

Lederer, A.L. and Mendelow, A.'. "Iss:es in !n"

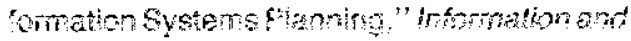
Mangement 10.5, May 486 , op $245-249$. Lucas, H. ir infomation Systemeroncepts for

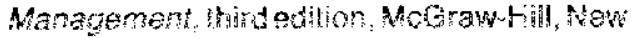
Yoik NY, 1988.

t.1nd, R. "Indiract Potioipetion, Infuerve, and Power: Srme Danish Experiences." Oraniza. tion Stivdies (1:2), 1930 , po 147.600

MoCabe, T.J. "A Complaxity Measure," IEEE Transactions on Sofware Engineoming Not. SE2, Cecember 8976, pp. $308-360$.

Mokeen, J.D. and Genmarase, T. "SeloctnoMls Projects by Stering Commithe," Communtotions of he ACW (es 2), 1985 pp 134t-1352

Nolson, E A Managementhanbook to the Es

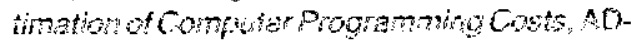
A648750, System Development Compration. Sarta Monica, CA October 31,1900

Ooni, W.Q. "A Comsensua! Framework ty the Design of Organindionat Cormol Mechan.

Copyright $\odot 2001$. All Rights Reseved. 
isms," Management Sciences (25:9), September 1979 , pp. 833-848.

Pfeffer, J. Organizational Design, Ahm Publishing Corp., Arlington Heights, IL, 1978.

Pfeffer, J. Power in Organizations, Pitmen Publishing, Inc., Marshfield, MA, 1981.

Putnam, L.H. "A General Empirical Solution to the Macro Sottware Sizing and Estimating Problem," IEEE Transactions on Software Engineering, July 1978, pp. 345-361.

Robey, D. and Markus, M.L. "Rituals in Information System Design," MIS Quarterly (8:1), March 1984, pp. 5-15.

Roethlisberger, F.J. The Elusive Phenomena, Harvard Business School, Division of Research, Boston, MA, 1977.

Thompson, J.D. Organizations in Action, McGrawHill, New York, NY, 1967.

Thompson, J.D. and Tuden, A. "Strategies, Structures and Processes of Organizational Decision," in Comparative Studies in Administration, J.D. Thompson, P.B. Hammond, R.W. Hawkes, B.H. Junker and A. Tuden (eds.), University of Pittsburgh Press, Pittsburgh, PA, 1959, pp. 195-216.

Walston, C.E. and Felix, C.P. "A Method of Programming Measurement and Estimation," $/ B M$ Systems Journal (16:1), 1977, pp. 54-73.

Wildavsky, A. The Politics of the Budgeting Process, third edition, Little, Brown and Company, Boston, MA, 1979.

Wolverton, R.W. "The Cost of Development LargeScale Software," IEEE Transactions on Computers, June 1974, pp. 615-636.

\section{About the Authors}

Albert $L$. Ledterer is associate professor and acting chair, Department of Decision and Information Sciences, School of Business Administration, Oaktand University. He formerly taught at the Ohio State University and the University of Pittsburgh. He spent over 10 years in industry in the MiS field. He has a Ph.D. in industrial and systems engineering from the Ohio State University, an M.S. in computer and information sciences from Ohio State, and $\mathrm{a}$ B.A. in psychology from the University of Cincinnati. This article is his fourth in the MIS Quarterly. Others on MIS have appeared in Sloan Management Review, Decision Sciences, Journal of MIS, Information and Management, Interfaces, Information Systems Research (forthcoming), and several other journals.
Rajesh Mirani is assistant professor in the Information and Quantitative Sciences Department of the Merrick School of Business at the University of Baltimore. He received his B.Tech. in chemical engineering from the Indian Institute of Technology, Kharagpur, and his M.B.A. from the Indian Institute of Management, 'Calcutta. He is com. pleting his Ph.D. at the University of Pittsburgh's Katz Graduate School of Business. His primary research interests are in end-user support in information centers, implementation issues in MIS, and decision support systems. He is actively involved in several research projects in these areas and is also working on a chapter on MIS in d forthcoming book on organizations.

Boon Siong Neo is a CPA and has an M.B.A. and a Ph.D in MIS from the Katz Graduate School of Business at the University of Pittsburgh. He is a lecturer at the School of Accountancy and Commerce, Nanyang Technological Institute, Singa pore. He has working experience in multindtional companies like Hewlett Packard and Shell Petroleum. In his doctoral dissertation, he studied the factors motivating companies to use strategic IT applications and the factors enabling them to achieve competitive advantage.

Carol E. Pollard, an assistant professor at Duquesne University, received her B.Sc. in information science from the University of Pittsbu $\mathrm{rgh}$ at Greensburg and her M.8.A. from the Katz Graduate School of Business (KGSB) at the University of Pittsburgh. She is a doctoral candidate in MIS with a minor in cognitive psychology at the KGSB where she was named a pre-doctoral fellow. She is a member of TIMS. Her research interests include behavioral issues in M!IS implementation and usage and the impacts of information technological innovation in organizations. Her current research interests focus on the use of group decision support systems in organizations and the impact of computer support on group processes and group and organizational outcomes.

Jayesh Prasad is completing his doctoral dissertation in information technology implementation at the Joseph M. Katz Graduate School of Búsiness at the University of Pittsburgh. He will igin the Department of MIS and Decision Sciences at the School of Business Administration of the University of Dayton this fall as assistant professor. He received his $B$. Tech. from the Indian Inst tute of Technology, Kharaghpur, in naval architecture and his M.B.A. from the Indian Institute of Manage- 
ment, Calculla His other research interests include M!S planining ranagement of M!S cersornel, and the politics intormation syeteris. Prior to beginnirg his doctoralstudies, he woiked in indusiry as an information systems aralyst.

K. Ramamuthy is ar assistant protessor in the NiS Department at the Universily of Wisconsin-Mi! weukee. He has an M. B.A. from Concondin University a gratuat diploma in statisics ant operations researchtrom the Indian Siatstical In. stitute, a S.E. fiom the University of Mattas and

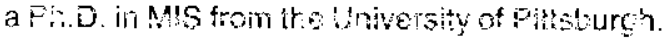
His industy experience of over 19 yen's indudes

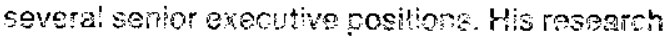
interests are $n_{1}$ the adopton of modern infma tion technotules, strategic MG plaming, ard decision suppont systems. te has papers in iefereed conterence prosectings such as the lntar-

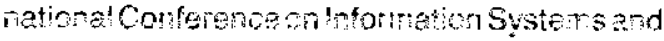
the Winter Simulation Conference Me tas apaper fortroming in Decistor Sorences. 